\title{
Baseline assessment of prevalence and geographical distribution of HPV types in Chile using self-collected vaginal samples
}

\author{
Catterina Ferreccio*1, Alejandro Corvalán ${ }^{\dagger 1}$, Paula Margozzini ${ }^{\dagger 1}$, \\ Paola Viviani ${ }^{\dagger 1}$, Claudia González ${ }^{\dagger 2}$, Ximena Aguilera ${ }^{\dagger 2}$ and Patti E Gravitt ${ }^{\dagger 3}$
}

\begin{abstract}
Address: ${ }^{1}$ P. Universidad Católica de Chile, Escuela de Medicina, Santiago Chile, ${ }^{2}$ Departamento de Epidemiología, Ministerio de Salud, Santiago Chile and ${ }^{3}$ The Johns Hopkins University, Bloomberg School of Public Health. Baltimore, USA

Email: Catterina Ferreccio* - cferrec@med.puc.cl; Alejandro Corvalán - corvalan@med.puc.cl; Paula Margozzini - pmargoz@med.puc.cl; Paola Viviani - paolav@mat.puc.cl; Claudia González - cgonzale@minsal.cl; Ximena Aguilera - xaguiler@minsal.cl; Patti E Gravitt - pgravitt@jhsph.edu

* Corresponding author †Equal contributors
\end{abstract}

Published: 28 February 2008

BMC Public Health 2008, 8:78 doi:10.1 I86/147/-2458-8-78
Received: 20 August 2007

Accepted: 28 February 2008

This article is available from: http://www.biomedcentral.com/I47I-2458/8/78

(c) 2008 Ferreccio et al; licensee BioMed Central Ltd.

This is an Open Access article distributed under the terms of the Creative Commons Attribution License (http://creativecommons.org/licenses/by/2.0), which permits unrestricted use, distribution, and reproduction in any medium, provided the original work is properly cited.

\begin{abstract}
Background: Chile has broad variations in weather, economics and population from the far desert north (Region I) to the cold, icy south (Region 12). A home-based self-collected vaginal sampling was nested in the 2003 Chilean population-based health survey in order to explore the possibility of a type-specific geographical variation for human papillomavirus
\end{abstract}

Methods: The population was a national probability sample of people 17 years of age and over. Consenting women provided self-collected cervicovaginal swabs in universal collection media (UCM). DNA was extracted and typed to $37 \mathrm{HPV}$ genotypes using PGMY consensus PCR and line blot assay. Weighted prevalence rates and adjusted OR were calculated.

Results: Of the I,883 women participating in the health survey, I,219 (64.7\%) provided a cervicovaginal sample and in I,I IO (56.2\% of participants and $66.5 \%$ of those eligible) the samples were adequate for analysis. Refusal rate was $16.9 \%$. HPV prevalence was $29.2 \%$ (I5.1\% high-risk HPV and 14.1\% low-risk HPV). Predominant high-risk types were HPV 16, 52, 5I, 56 and 58. Predominant low-risk HPVs were HPV 84, CP6I 08, 62, 53 and 61. High-risk and low-risk HPV rates were inversely correlated between the regions. High-risk HPV prevalence was highest among the youngest women, whereas low-risk HPV increased slightly with age.

Conclusion: Self-obtained vaginal sampling is adequate for monitoring HPV in the community, for identifying high-risk areas, and for surveying the long term impact of interventions.

\section{Background}

The availability of highly effective human papillomavirus (HPV) vaccines has led to a discussion about their incorporation in public health vaccine programs $[1,2]$. A baseline characterization of HPV types in cervical cancers and also in the general population is required before deciding whether to introduce the vaccine. With this information on the population genotype prevalence, together with regional specific genotype distribution in cervical lesions and cervical cancer, the potential impact of the vaccine can be estimated. In a previous study of HPV prevalence in cervical specimens of a population-based sample of 
women, we explored the individual risk factors for lowrisk and high-risk HPV infections, confirming that in Chile the main risk factor was the number of sexual partners for both high and low risk HPV [3]. This study aims to describe the geographical distribution of the HPV types in the national community. Epidemiologic studies of the prevalence of HPV in the community have typically used cervical samples obtained by a gynaecological examination [4]. Most women find this exam to be uncomfortable [5]. Additionally, in countries where Papanicolaou (PAP) screening is not widely accepted, studies based on gynaecological sampling may not represent the general population. For community surveillance, public health officers will need non-invasive methods that are acceptable to a representative sample of women. One option is the selfobtained vaginal sample. Various well-designed trials have demonstrated that HPV detection using selfobtained vaginal sample is a reasonable surrogate for the identification of HPV types that are infecting the cervix, with moderate to excellent agreement with the detection of HPV from cervical samples obtained by clinicians [610]. Agreement was better for the high-risk HPVs $[6,8,11,12]$. Studies comparing acceptability of methods demonstrated that most women preferred self-vaginal sampling [5,8,13-19]. We assessed the prevalence and distribution of HPV types throughout Chile using selfobtained vaginal sampling in the community. The National Health Survey, ENS 2003, the first prevalence study of chronic diseases, provided a population-based national sample of non-institutionalized people aged 18 and above [20]. This is one of the first studies with selfobtained vaginal sampling in a health survey for chronic conditions in the adult population. The aims were to assess the magnitude of the problem and to explore the association of HPV prevalence with some regional characteristics.

Chile is a long (6,435 km length) and narrow (200 km wide) country (Figure 1 ) with a climate that goes from the driest desert in the world, with a mean temperature of $18.1^{\circ} \mathrm{C}$ and $0 \mathrm{~mm}$ of rain/year in the extreme north (Region 1$)$ to a cold, windy and rainy $(3,500 \mathrm{~mm}$ yearly) climate in the far south (Region 12). The population in the northern regions resides mostly in urban areas, with a racial admixture of Hispanic and Andean Indians. Its main economic activity is copper mining. Most of the Chilean population lives in the central regions. The metropolitan area (Region 13) is located between Regions 5 and 6; the climate is temperate with an average of $15^{\circ} \mathrm{C}$ and an average annual rainfall of $150-200 \mathrm{~mm}$. Its main economic activity is industry and wine production. The population is an admixture of Spanish with native Mapuche Indians. The southern regions are mountainous, with many lakes and rivers, and large rural population. Average rainfall is $1,500-2,000 \mathrm{~mm} /$ year, with a tempera- ture range of $2{ }^{\circ} \mathrm{C}-23^{\circ} \mathrm{C}$. This area hosts the largest ethnic Mapuche population and is the poorest in the country. Its main economic activity is agriculture and livestock production. The far southern regions have a cold climate and their principal activity is fisheries; its native population is the lowest in the country.

\section{Methods \\ Population and sample}

The study population included all women participating in the ENS 2003. The sample for the ENS 2003 was a national stratified multistage probability sample of noninstitutionalized people aged 18 years and above, representing the Chilean population and comparing regions, rural and urban, four age groups, and three socio-economic strata. The sampling error was set at less than $2 \%$. The ENS 2003 is the first household based health survey with biological sampling (blood, urine) body measurements (height, weight, waist circumference), clinical examinations (visual and auditive acuity, dental health) and comprehensive health questionnaires administered by a public health certified nurse and a trained interviewer. Only one subject, selected by the Kish method, participated per household [21]. The survey was conducted from June to December 2003. The ethics committees of the Catholic University and the Ministry of Health reviewed and approved the study. All women signed a separate informed consent for the self-obtained vaginal sample.

\section{Self-obtained vaginal sampling}

After receiving information about the exam and providing written informed consent, eligible women who were not menstruating, not pregnant, had not had sexual relations the previous day, with no prior hysterectomy, and had initiated sexual activity were taught, using pictorial pamphlets, how to obtain a vaginal sample. The nurse provided a Digene sachet containing a conical brush and a tube with the transport media (Universal Collection Media, UCM) [22]. Women were instructed to introduce the brush deep into their vagina and turn it smoothly once towards the left and then towards the right. They then were instructed to place the brush in the tube, cover it with a lid and give it to the nurse. Tubes were transported and stored at $4^{\circ} \mathrm{C}$ until processing. Most samples were processed 35 days after the exam was taken, with a range of 10 days to four months, with no difference in positivity rate with regard to the time elapsed before processing. A PAP screening was recommended for women with an HPV positive result.

\section{Laboratory analysis}

In the Catholic University Pathology Laboratory, DNA from the self-obtained vaginal sample was extracted with the DNeasy tissue kit (Qiagen, Valencia, CA USA) follow- 


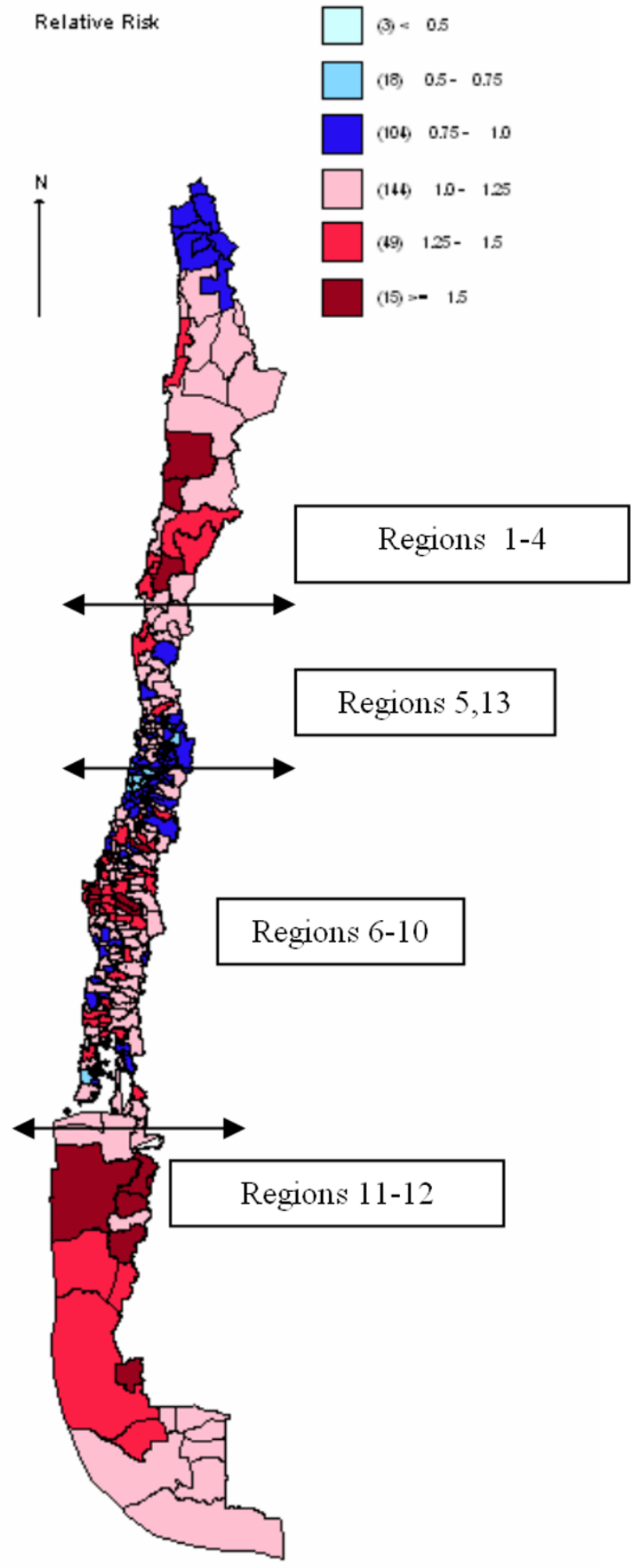

Figure I

Relative Risk of cervical cancer mortality by county of residence. Chile average 1985-2002(I) I: Prepared by the authors based on Ministry of Health mortality and population data. 
ing the manufacturer's instructions. All extracted DNA samples were sent to Johns Hopkins University where they were typed using PGMY consensus PCR and prototype line blot assay (Roche Molecular Systems) to identify 37 HPV genotypes [23-25]. DNA extraction, PCR set-up and amplification/detection were conducted in separate laboratories using dedicated instruments to minimize contamination. Specimens were opened only after brief centrifugation using clean Kim-wipe to avoid specimento-specimen carryover. Each 96 well PCR plate included eight DNA negative controls. HPV 16 and 18 positive plasmid controls in a background of $50 \mathrm{ng} / \mathrm{ml}$ human placental DNA at high (approx 5000 copies/PCR) and low (approx 25 copies/PCR) concentration were also included in each PCR assay. Two negative controls per detection tray were included to ensure no spill over during hybridization.

\section{Collection of secondary data from Chilean Regions}

To explain the variation in the prevalence of HPV among the 13 Chilean Regions, we collected available regional population data for women's characteristics (fertility rate, educational level, smoking rate), socio-demographic characteristics (life expectancy, percent Amerindians, percent single, poverty index, age distribution), access to health care (Papanicolaou coverage), HIV prevalence rate (indicator of sexually transmitted diseases) and cervical cancer mortality. We obtained mortality data and health information from the Ministry of Health and population data from the National Institute of Statistics.

\section{Statistical analysis}

Prevalence rates were calculated using sampling weights based on the two stage sampling design and adjusted for post stratification population totals using the Chilean 2003 population statistics. Considering the complex sample design, the standard error and 95 percent confidence intervals were calculated with the Taylor linear approximation method using SPSS version 14 [26]. Adjusted OR for high-risk and low-risk infections were calculated from a Multivariate Logistic Regression Model for Complex Samples. Age adjusted high risk and low risk HPV prevalence, were calculated with a general additive model using $\mathrm{R}$ software. For the exploratory regional-level analyses of HPV and some regional characteristics partial correlations were used adjusted by age and multivariate linear models using SPSS 14.

\section{Results}

\section{Survey response rates}

A total of 1,883 women participated in the ENS2003; 12\% were not eligible - reasons for ineligibility included women currently menstruating, having had sexual intercourse less than 24 hours previously $(9.1 \%)$, or prior hysterectomy $(2.9 \%) ; 8.1 \%$ could not be included because the interviewers did not have swabs when conducting the survey; $16.9 \%$ refused to take the self-sample leaving a total of $1,219(64.7 \%)$ women who provided a self exam. $109(8.9 \%)$ of the samples were insufficient for HPV analysis as indicated by the absence of the human beta-globin control amplification (1.6\%) or were untested because the tube was broken or empty. Therefore, 1,110 women (56.2\% of the participants and $66.5 \%$ of the eligible women) provided an analyzable vaginal sample. Women refusing to collect the sample were similar to those who accepted the exam with regard to region of residence and urban-rural zone, but higher refusals were observed among the younger $(<25$ years old $)$, the older $(>60$ years old), the lower educational group, the single, and the widowed.

\section{Population characteristics}

The mean age of the survey participants was 41.9 years (range 16-97) and the majority lived in urban areas $(88.1 \%)$ (Table 1$)$. The mean number of years of education was 9.4 (range $0-22$ ); $26 \%$ had less than 4 years of education. The majority of participants $(62.5 \%)$ were unemployed (i.e., not working or studying) and were married or cohabiting (66\%). The survey population was reasonably well-screened, with $85 \%$ of women reported having a previous Papanicolaou smear (62\% in less than 3 years), and $2.6 \%$ reporting having had a previous abnormal Papanicolaou smear. The regional distribution of participants represents the baseline population.

\section{Acceptability of self-sampling}

Most women [89.6\%, (95\% CI 86.8-91.9)] reported no discomfort with the self-administered swabs and the majority [79.4\% (95\%CI 75.9-82.6)] indicated self sampling caused less discomfort than the Papanicolaou smear (manuscript in preparation).

\section{HPV prevalence: Regional variation by risk group}

Overall, we observed $29.2 \%$ point prevalence for any HPV infection in a population-based survey of adult Chilean women. Of the infected women, $146(15.3 \%)$ had at least one high risk HPV genotype detected and $83(8.4 \%)$ had exclusively high-risk HPV types. Only low-risk HPV types were detected in the remaining infected women $(162$, or $13.9 \%$ of the survey population). A total of 488 infections were identified (some women may be infected with more than one HPV type); of those 202 (41.4\%) were caused by high-risk HPVs and $286(58.6 \%)$ by low-risk HPVs. HPV 16 was the predominant type of high-risk HPV, followed by HPV 52, 51, 56 and 58. Among the low-risk HPVs the most frequently detected types were HPV 84, CP6108, 62, 53 and 61 (Table 2).

Total HPV infection (high-risk plus low-risk HPVs) varied from 43.5\% (95\% IC, 23.5-65.9) in Region I (the north- 
Table I: Characteristics of the I I 10 women studied and weighted percents.

\begin{tabular}{|c|c|}
\hline Characteristics (n) & (n) weighted percent $*$ \\
\hline \multicolumn{2}{|l|}{ Age (years) } \\
\hline $18-24$ & (102) 13.1 \\
\hline $25-29$ & $(73) 10.2$ \\
\hline $30-34$ & (104) 13.4 \\
\hline $35-39$ & $(90) \quad 11.6$ \\
\hline $40-44$ & (II4) 11.6 \\
\hline $45-49$ & (129) 10.7 \\
\hline $50-54$ & (109) 8.4 \\
\hline $55-59$ & $(94) 6.2$ \\
\hline $60-64$ & (83) 5.8 \\
\hline$>=65$ & (2I2) 9.0 \\
\hline \multicolumn{2}{|l|}{ Education } \\
\hline High & (I28) 16.6 \\
\hline Medium & (556) 57.2 \\
\hline Low & (426) 26.2 \\
\hline \multicolumn{2}{|l|}{ Marital status } \\
\hline Married/Cohabiting & (674) 65.8 \\
\hline Widow & $(121) 5.3$ \\
\hline Separated & (85) 5.7 \\
\hline Single & (228) 23.1 \\
\hline \multicolumn{2}{|l|}{ Smoker } \\
\hline No & (735) 60.1 \\
\hline Yes & 39.9 \\
\hline \multicolumn{2}{|l|}{ Pap ever } \\
\hline Yes & (939) 84.6 \\
\hline No & (167) 15.4 \\
\hline \multicolumn{2}{|l|}{ Residence } \\
\hline Urban & (947) 88.1 \\
\hline Rural & (163) 11.9 \\
\hline \multicolumn{2}{|l|}{ Region } \\
\hline North & $12.0 \%(10.5-13.7)$ \\
\hline Central & $54.0 \%(50.3-57.6)$ \\
\hline South & $32.9 \%(29.7-36.3)$ \\
\hline Extreme South & $1.1 \%(0.8-1.4)$ \\
\hline
\end{tabular}

*::using sampling weights and adjusted for post stratification population totals.

ernmost region) to 25\% (96\% CI, 15.6-36.6) in Region V (Figure 2). Prevalence of high-risk (either single or multiple) and low-risk HPVs (single or multiple low-risk only) rates were inversely correlated between the regions (Pearson correlation $-0.62 \mathrm{p}=0.023)$. Although not statistically significant the age distribution varied between the regions with the lowest mean age in Region I and the highest in Region XII (mean age in years 38.6 and 45.0, respectively). When weighted and age-adjusted, this inverse association between high and low-risk HPVs decreased and lost its statistical significance (age adjusted partial correlation $-0.36 \mathrm{p}=0.25)$. Based on the relative contribution of a high-risk HPV to the total burden of HPV, four distinct macroregions were identified: the North (adjacent to Peru and Bolivia), Central, South, and Extreme South (Patagonia). The OR of having high-risk HPVs was 2.8 (95\% CI 1.4-5.7), 0.9 (95\% CI 0.6-1.5), 0.6 (95\% CI
0.3-0.98) and 1.09 (95\% CI 0.4-3.0), for the North, Central, South and Extreme South areas respectively. The mean ages of the population were: $39.8,42.7,41.1$ and 40.0 for North, Central, South and Extreme South regions, respectively. Neither high-risk HPV nor low-risk HPV was associated with cervical cancer mortality (Pearson correlation 0.2 and 0.1 respectively; test for trend, $p=0.29$ and 0.37 , respectively). In 2004, according to the ministry of health statistics, the Papanicolaou coverage for women 35-64 years old varied from 54.7\% in the Metropolitan South-eastern Health Service to $87.3 \%$ in the Metropolitan Central Health Service. Nevertheless, Papanicolaou coverage was not significantly associated with either highrisk (Pearson correlation $0.15 p=0.6$ ) or low-risk HPV (Pearson correlation $-0.35 p=0.23$ ).

The prevalence of current smokers, birth-rate and malefemale ratio (number of men divided by number of women in the baseline population) correlated significantly with the prevalence of high-risk HPV (Pearson correlation and p values $0.63,0.01 ; 0.47,0.05$ and $0.47,0.05$, respectively). Prevalence of current smokers, prevalence rate of HIV and proportion of singles, were inversely correlated with low-risk HPV (Pearson correlation and $\mathrm{p}$ value $-0.45,0.059 ;-0.50,0.04$, respectively and 0.43 , $0.069)$.

\section{Individual risk factors for HPV infection}

High-risk HPV prevalence was highest in the younger age group (under 25 years old) and declined significantly with age (Figure 3 ). Low-risk HPV had a positive but not statistically significant increase with age (Figure 4). Single women had a higher prevalence of high-risk HPV infection $(\mathrm{OR}=3.795 \%$ confidence interval (CI) 2.1-6.6) while women who were older $(\mathrm{OR}=0.29,95 \% \mathrm{CI}$; $0.1-0.8$ ) and living in a rural area $(\mathrm{OR}=0.2595 \% \mathrm{CI}$ 0.1-0.7) were significantly less likely to have prevalent high-risk HPV (Table 3). Ever having had a Papanicolaou was unrelated with either high-risk or low-risk HPV. We found no association between either high-risk or low-risk HPV and years of education. After multivariate adjustment, the only risk factors for low-risk HPV were being separated $(\mathrm{OR}=2.195 \% \mathrm{CI} 1.2-3.7)$ and residing in the southern regions $(\mathrm{OR}=2.395 \%$ CI 1.4-3.7) (Table 3).

\section{Discussion}

Surveillance of adult health status and its risk factors has become an essential tool for public health planning and evaluation. To date this surveillance has focused on cardiovascular diseases and its risk factors and, therefore, this is one of the first surveys to incorporate HPV testing as one of the priority problems for adult health surveillance. The overall prevalence of any HPV was strikingly similar to a recent US national survey using similar methods; however we did note an interesting contrast between high-risk and 
Table 2: HPV infections by HPV types in vaginal samples of I, I 10 women from the National Health Survey 2003.

\begin{tabular}{|c|c|c|c|c|c|}
\hline HPV type & Single & Multiple & Total (crude \%) & $\%$ adjusted $*$ & $95 \% \mathrm{Cl}$ adjusted \\
\hline HPV - & & & $802(72.3)$ & 70.8 & $(66.3-74.9)$ \\
\hline $\mathrm{HPV}+$ & 208 & 100 & $308(27.7)$ & 29.2 & $(25.1-33.7)$ \\
\hline HR HPV+ & 70 & 76 & $146(13.2)$ & 15.3 & $(11.9-19.3)$ \\
\hline HR HPV only & 70 & 13 & $83(7.5)$ & 8.4 & $(5.9-11.8)$ \\
\hline LR HPV+ only & 138 & 24 & $162(14.6)$ & 13.9 & (II.2-17.2) \\
\hline \multicolumn{6}{|l|}{ HR infections } \\
\hline 16 & 19 & 10 & $29(2.6)$ & 3.2 & $(1.6-6.3)$ \\
\hline 18 & 1 & 5 & $6(0.5)$ & 0.3 & $(0.1-0.8)$ \\
\hline 31 & 5 & 7 & $12(1.1)$ & 1.2 & $(0.6-2.5)$ \\
\hline 33 & 1 & 5 & $6(0.5)$ & 0.4 & $(0.2-1.2)$ \\
\hline 35 & 4 & 6 & $10(0.9)$ & I.I & $(0.5-2.2)$ \\
\hline 39 & 4 & 7 & II (I.0) & 1.3 & $(0.5-3.2)$ \\
\hline 45 & 5 & 7 & $12(1.1)$ & 0.9 & $(0.4-1.8)$ \\
\hline 51 & 6 & 11 & $17(1.5)$ & 2.1 & $(1.0-4.3)$ \\
\hline 52 & 5 & 19 & $24(2.2)$ & 2.6 & $(1.3-4.9)$ \\
\hline 56 & 4 & 11 & $15(1.4)$ & 2.0 & $(0.8-4.9)$ \\
\hline 58 & 2 & 17 & $19(1.7)$ & 1.7 & $(1.0-3.0)$ \\
\hline 59 & 7 & 4 & II (I.0) & 1.6 & $(0.7-3.3)$ \\
\hline 66 & 3 & 9 & $12(1.1)$ & 1.6 & $(0.6-4.0)$ \\
\hline 68 & 3 & 5 & $8(0.7)$ & 0.5 & $(0.2-1.2)$ \\
\hline 73 & 1 & 9 & $10(0.9)$ & 1.0 & $(0.5-2.3)$ \\
\hline Subtotal & 70 & 132 & 202 & & \\
\hline \multicolumn{6}{|l|}{ LR infections } \\
\hline 6 & 5 & 4 & $9(0.8)$ & 1.2 & $(0.5-2.6)$ \\
\hline 11 & I & 0 & $\mathrm{I}(0.1)$ & 0.1 & $(0.0-1.0)$ \\
\hline 26 & 1 & 1 & $2(0.2)$ & 0.1 & $(0.0-0.4)$ \\
\hline 40 & 1 & 2 & $3(0.3)$ & 0.2 & $(0.0-0.8)$ \\
\hline 42 & 2 & 10 & $12(I . I)$ & 1.2 & $(0.6-2.4)$ \\
\hline 53 & 8 & 16 & $24(2.2)$ & 2.6 & $(1.2-5.6)$ \\
\hline 54 & 2 & 6 & $8(0.7)$ & 0.3 & $(0.1-0.7)$ \\
\hline 55 & 4 & 3 & $7(0.6)$ & 0.6 & $(0.2-1.7)$ \\
\hline 61 & 20 & 15 & $35(3.2)$ & 2.3 & $(1.4-3.8)$ \\
\hline 62 & 10 & 16 & $26(2.3)$ & 3.1 & $(1.8-5.3)$ \\
\hline 64 & 3 & 0 & $3(0.3)$ & 0.1 & $(0.0-0.3)$ \\
\hline 67 & 4 & 5 & $9(0.8)$ & 1.4 & $(0.5-4.0)$ \\
\hline 70 & 9 & 12 & $21(1.9)$ & 1.8 & $(1.1-3.1)$ \\
\hline 71 & 6 & 13 & $19(1.7)$ & 1.3 & $(0.7-2.7)$ \\
\hline 72 & 10 & 1 & II (I.0) & 1.0 & $(0.4-2.2)$ \\
\hline 81 & 9 & 9 & $18(1.6)$ & 2.0 & $(1.0-4.0)$ \\
\hline 83 & 8 & 4 & $12(1.1)$ & 0.8 & $(0.3-1.7)$ \\
\hline 84 & 21 & 14 & $35(3.2)$ & 3.7 & $(2.3-6.1)$ \\
\hline CP6108 & 12 & 14 & $26(2.3)$ & 3.2 & $(1.8-5.5)$ \\
\hline IS39 & 2 & 3 & $5(0.5)$ & 0.8 & $(0.2-2.3)$ \\
\hline Subtotal & 138 & 148 & 286 & & \\
\hline Total & 208 & 280 & 488 & & \\
\hline
\end{tabular}

HR: high-risk, LR: low-risk; *::using sampling weights and adjusted for post stratification population totals

low-risk HPV prevalence and regional variability that was not previously reported [27].

In the multivariate analysis, residing in the north of Chile was a risk factor for high-risk HPV infection. The relative contribution of high risk HPV to the total burden of HPV infection was almost 3 times higher in the north than the national average while in the south it was almost half the national average [OR 2.8 (95\% CI, 1.4-5.7) and 0.6 (95\% CI, 0.3-0.98), respectively]. The relative excess of highrisk types in the north appears to be associated with a younger age and with variations in factors associated with sexual behaviour. While we could not explore sexual behaviour directly, secondary data shows that northern regions have higher rates of smoking, higher birth rates and higher rates of HIV while they are less rural and have 


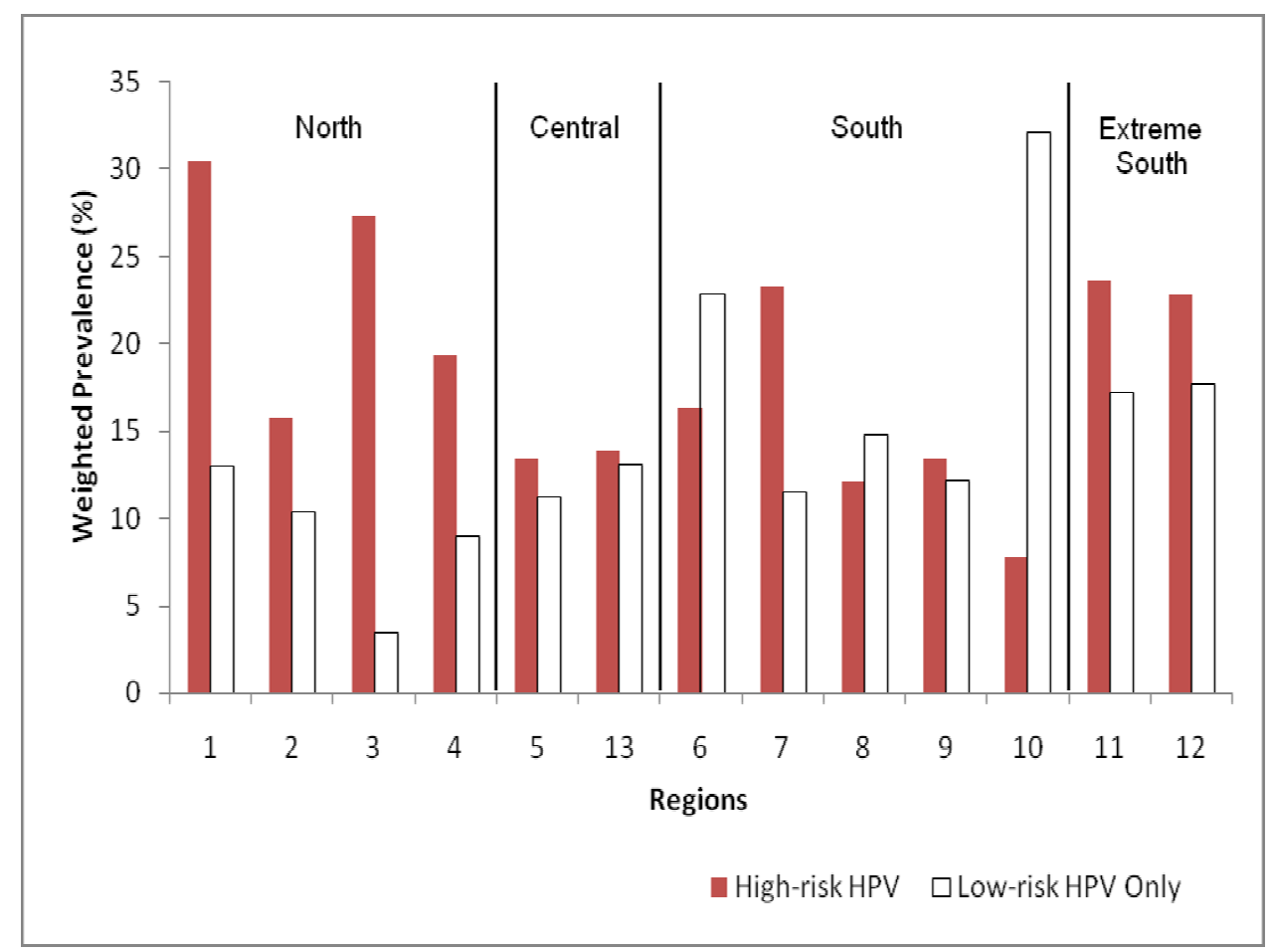

Figure 2

Regional distribution high-risk and low-risk HPV in the population of Chile's I3 Regions.

less poverty than the southern regions (data not presented). On the other hand, the excess of low- risk HPV in the south appears to be associated with older age, poverty and rurality. Other authors have also described a diverse epidemiological profile for low and high risk HPVs $[4,28]$.

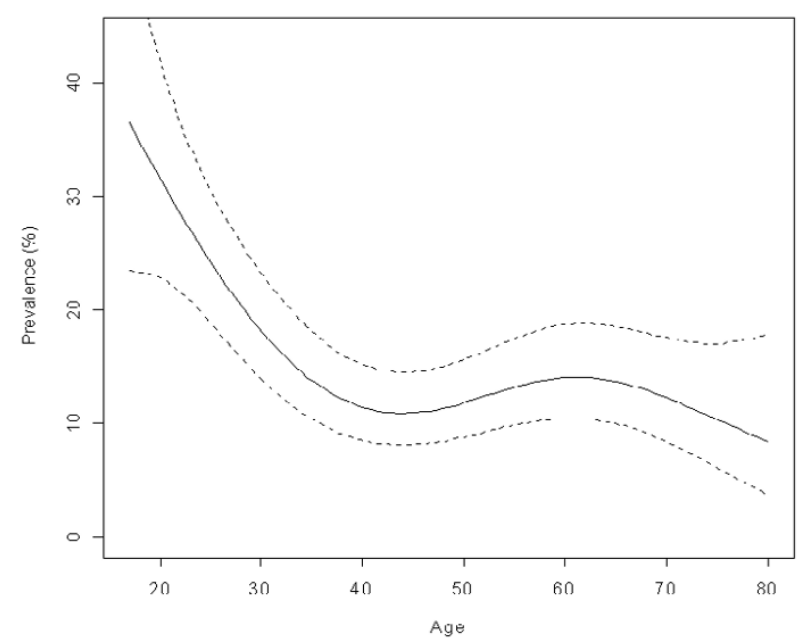

Figure 3

Age prevalence of high-risk HPV in vaginal samples from the population. National Health Survey, Chile 2003.
To explain the differences in the relative distribution of high and low risk HPV, some authors have suggested an antagonism between high-risk and low-risk HPVs. In a serologic case-control study, Luostarinen, et al. [29]

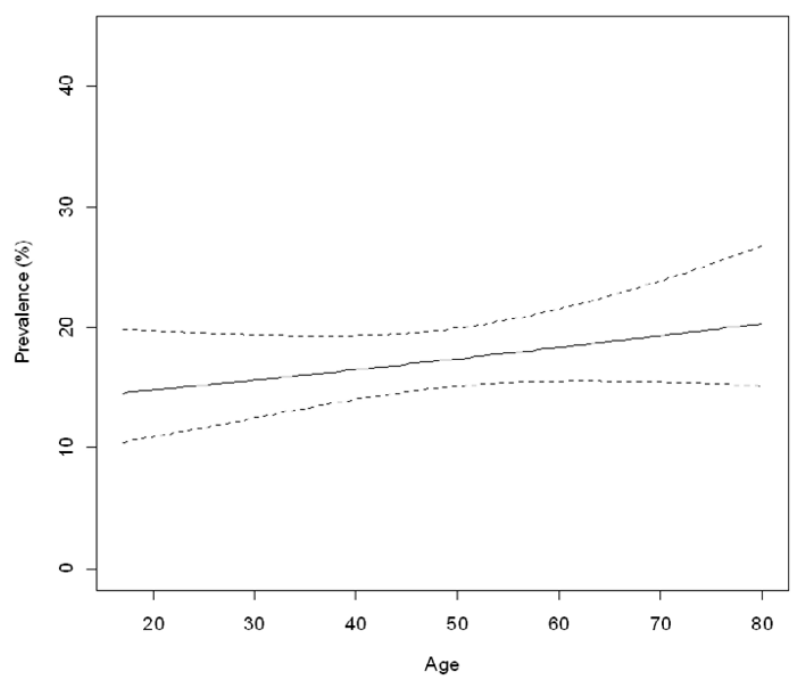

Figure 4

Age prevalence of low-risk HPV in vaginal samples from the population. National Health Survey, Chile 2003. 
Table 3: Risk factors for HPV infection among the I I 10 women, National Health Survey, Chile 2003.

\begin{tabular}{|c|c|c|c|c|c|c|}
\hline Characteristics (n) & $\begin{array}{c}\text { HR HPV } \\
(95 \% \text { IC) } \\
n=146\end{array}$ & $\begin{array}{c}\text { Crude OR } \\
(95 \% \text { IC) }\end{array}$ & $\begin{array}{c}\text { Adjusted OR } \\
\text { (95\% IC) }\end{array}$ & $\begin{array}{l}\text { LR HPV only } \\
(95 \% \text { IC) } \\
n=162\end{array}$ & $\begin{array}{c}\text { Crude OR } \\
(95 \% \text { IC) }\end{array}$ & $\begin{array}{l}\text { Adjusted OR } \\
\text { (IC 95\%) }\end{array}$ \\
\hline \multicolumn{7}{|l|}{ Age (years) } \\
\hline $18-29$ & $\begin{array}{c}26.8 \\
(18.5-37.1)\end{array}$ & 1.0 & 1.0 & $\begin{array}{c}13.7 \\
(8.2-22.0)\end{array}$ & 1.0 & 1.0 \\
\hline $30-49$ & $\begin{array}{c}13.9 \\
(9.1-20.7)\end{array}$ & $\begin{array}{c}0.5 \\
(0.3-0.9)\end{array}$ & $\begin{array}{c}0.7 \\
(0.4-1.4)\end{array}$ & $\begin{array}{c}13.0 \\
(9.2-18.1)\end{array}$ & $\begin{array}{c}1.3 \\
(0.7-2.4)\end{array}$ & $\begin{array}{c}0.8 \\
(0.3-2.0)\end{array}$ \\
\hline $50-64$ & $\begin{array}{c}8.5 \\
(5.7-12.5)\end{array}$ & $\begin{array}{c}0.8 \\
(0.4-1.4)\end{array}$ & $\begin{array}{c}0.4 \\
(0.2-0.99)\end{array}$ & $\begin{array}{c}15.6 \\
(10.4-22.6)\end{array}$ & $\begin{array}{c}1.3 \\
(0.7-2.6)\end{array}$ & $\begin{array}{c}0.9 \\
(0.3-2.3)\end{array}$ \\
\hline$>=65$ & $\begin{array}{c}8.0 \\
(4.6-13.5)\end{array}$ & $\begin{array}{c}0.4 \\
(0.2-0.99)\end{array}$ & $\begin{array}{c}0.3 \\
(0.1-0.8)\end{array}$ & $\begin{array}{c}16.1 \\
(10.7-23.6)\end{array}$ & $\begin{array}{c}1.8 \\
(0.8-3.8)\end{array}$ & $\begin{array}{c}0.9 \\
(0.3-2.4)\end{array}$ \\
\hline \multicolumn{7}{|l|}{ Education } \\
\hline High & $\begin{array}{c}17.0 \\
(9.2-29.3)\end{array}$ & 1.0 & 1.0 & $\begin{array}{c}16.2 \\
(8.5-28.5)\end{array}$ & 1.0 & 1.0 \\
\hline Medium & $\begin{array}{c}16.7 \\
(12.0-22.8)\end{array}$ & $\begin{array}{c}0.8 \\
(0.4-1.3)\end{array}$ & $\begin{array}{c}1.2 \\
(0.5-2.9)\end{array}$ & $\begin{array}{c}12.6 \\
(9.5-16.6)\end{array}$ & $\begin{array}{c}0.7 \\
(0.4-1.2)\end{array}$ & $\begin{array}{c}0.7 \\
(0.3-1.6)\end{array}$ \\
\hline Low & $\begin{array}{c}11.0 \\
(7.6-15.8)\end{array}$ & $\begin{array}{c}0.9 \\
(0.5-1.7)\end{array}$ & $\begin{array}{c}1.4 \\
(0.6-3.8)\end{array}$ & $\begin{array}{c}15.4 \\
(11.0-21.2)\end{array}$ & $\begin{array}{c}0.6 \\
(0.3-1.1)\end{array}$ & $\begin{array}{c}0.8 \\
(0.4-2.0)\end{array}$ \\
\hline $\begin{array}{l}\text { Marital st } \\
\text { Married/Cohabiting }\end{array}$ & $\begin{array}{c}10.0 \\
(6.7-14.7)\end{array}$ & 1.0 & 1.0 & $\begin{array}{c}12.9 \\
(9.7-17.1)\end{array}$ & 1.0 & 1.0 \\
\hline Widow & $\begin{array}{c}12.9 \\
(6.7-23.1)\end{array}$ & $\begin{array}{c}2.0 \\
(1.02-3.9)\end{array}$ & $\begin{array}{c}2.3 \\
(0.9-5.4)\end{array}$ & $\begin{array}{c}21.4 \\
(\mid 3.5-32.2)\end{array}$ & $\begin{array}{c}1.8 \\
(1.1-3.3)\end{array}$ & $\begin{array}{c}1.9 \\
(0.9-3.7)\end{array}$ \\
\hline Separated & $\begin{array}{c}6.8 \\
(3.0-14.4)\end{array}$ & $\begin{array}{c}1.1 \\
(0.5-2.3)\end{array}$ & $\begin{array}{c}0.7 \\
(0.2-2.0)\end{array}$ & $\begin{array}{c}26.5 \\
(14.8-42.6)\end{array}$ & $\begin{array}{c}2.1 \\
(1.2-3.7)\end{array}$ & $\begin{array}{c}2.5 \\
(1.1-5.7)\end{array}$ \\
\hline Single & $\begin{array}{c}33.2 \\
(24.8-42.8)\end{array}$ & $\begin{array}{c}2.7 \\
(1.7-4.2)\end{array}$ & $\begin{array}{c}3.7 \\
(2.1-6.6)\end{array}$ & $\begin{array}{c}12.3 \\
(7.6-19.2)\end{array}$ & $\begin{array}{c}1.3 \\
(0.83-2.2)\end{array}$ & $\begin{array}{c}0.9 \\
(0.5-1.7)\end{array}$ \\
\hline \multicolumn{7}{|l|}{ Smoker } \\
\hline No & $\begin{array}{c}11.8 \\
(8.3-16.6)\end{array}$ & 1.0 & 1.0 & $\begin{array}{c}13.9 \\
(10.6-18.1)\end{array}$ & 1.0 & 1.0 \\
\hline Yes & $\begin{array}{c}20.6 \\
(14.5-28.4)\end{array}$ & $\begin{array}{c}1.3 \\
(0.9-1.9)\end{array}$ & $\begin{array}{c}1.46 \\
(0.8-2.8)\end{array}$ & $\begin{array}{c}14.1 \\
(10.0-19.6)\end{array}$ & $\begin{array}{c}1.18 \\
(0.8-1.7)\end{array}$ & $\begin{array}{c}1.1 \\
(0.6-1.9)\end{array}$ \\
\hline \multicolumn{7}{|l|}{ Pap ever } \\
\hline Yes & $\begin{array}{c}14.0 \\
(10.4-18.6)\end{array}$ & 1.0 & 1 & $\begin{array}{c}13.9 \\
(10.9-17.5)\end{array}$ & 1.0 & 1.0 \\
\hline No & $\begin{array}{c}21.9 \\
(13.6-33.3)\end{array}$ & $\begin{array}{c}0.99 \\
(0.6-1.7)\end{array}$ & $\begin{array}{c}0.8 \\
(0.4-1.7)\end{array}$ & $\begin{array}{c}14.0 \\
(8.4-22.4)\end{array}$ & $\begin{array}{c}1.13 \\
(0.7-1.9)\end{array}$ & $\begin{array}{c}0.9 \\
(0.4-1.9)\end{array}$ \\
\hline \multicolumn{7}{|l|}{ Residence } \\
\hline Urban & $\begin{array}{c}16.7 \\
(12.9-21.2)\end{array}$ & 1 & 1.0 & $\begin{array}{c}13.6 \\
(10.7-17.1)\end{array}$ & 1.0 & 1.0 \\
\hline Rural & $\begin{array}{c}5.0 \\
(2.1-11.2)\end{array}$ & $\begin{array}{c}0.4 \\
(0.2-0.8)\end{array}$ & $\begin{array}{c}0.2 \\
(0.1-0.7)\end{array}$ & $\begin{array}{c}16.8 \\
(10.2-26.5)\end{array}$ & $\begin{array}{c}1.3 \\
(0.8-2.1)\end{array}$ & $\begin{array}{c}1.08 \\
(0.6-2.1)\end{array}$ \\
\hline \multicolumn{7}{|l|}{ Region } \\
\hline North & $\begin{array}{c}22.7 \\
(16.6-30.3)\end{array}$ & 1.0 & 1.0 & $\begin{array}{c}8.5 \\
(4.5-15.6)\end{array}$ & 1.0 & 1.0 \\
\hline Central & $\begin{array}{c}13.9 \\
(9.0-20.8)\end{array}$ & $\begin{array}{c}0.5 \\
(0.3-0.9)\end{array}$ & $\begin{array}{c}0.6 \\
(0.3-1.1)\end{array}$ & $\begin{array}{c}12.8 \\
(8.9-18.1)\end{array}$ & $\begin{array}{c}1.7 \\
(0.9-3.0)\end{array}$ & $\begin{array}{c}1.5 \\
(0.7-3.5)\end{array}$ \\
\hline South & $\begin{array}{c}14.5 \\
(9.9-20.6)\end{array}$ & $\begin{array}{c}0.6 \\
(0.4-0.88)\end{array}$ & $\begin{array}{c}0.7 \\
(0.4-1.3)\end{array}$ & $\begin{array}{c}18.0 \\
(14.0-22.9)\end{array}$ & $\begin{array}{c}2.3 \\
(1.4-3.7)\end{array}$ & $\begin{array}{c}2.4 \\
(1.1-5.0)\end{array}$ \\
\hline Extreme South & $\begin{array}{c}24.7 \\
(11.8-44.7)\end{array}$ & $\begin{array}{c}0.83 \\
(0.4-1.8)\end{array}$ & $\begin{array}{c}1.5 \\
(0.5-4.6)\end{array}$ & $\begin{array}{c}15.9 \\
(6.9-32.4)\end{array}$ & $\begin{array}{c}1.9 \\
(0.8-4.6)\end{array}$ & $\begin{array}{c}1.9 \\
(0.6-5.9)\end{array}$ \\
\hline
\end{tabular}

describe a statistically significant null association with cervical cancer risk among women who are seropositive to both HPV 6/11 $(\mathrm{OR}=1.0)$ and HPV 16, relative to HPV 6/ 11 alone $(\mathrm{OR}=2.2)$ or HPV 16 alone $(\mathrm{OR}=5.5)$. Similarly, Wheeler, et al. [30] observed that women who had no HPV had a five times higher probability of acquiring HPV 16 in the following two years than women who carried low-risk HPVs (authors' calculation from Table 2 of Wheeler 2006). These reports, coupled with our ecologic observational data of an inverse correlation between low 
and high risk HPV infections, not entirely controlled by age adjustment, point to possible immunological interactions between the cervicovaginal HPV flora that require further investigation.

The age-specific prevalence of HPV were the same in the current survey and in our previous study, with high-risk HPV prevalence peaking below 25 years old while lowrisk HPV increased slowly after age 50 [3]. The increase in the prevalence of low-risk HPV in older ages has been reported in some studies in Latin America and Spain [3133] and confirmed in a recent meta-analysis [34], whereas others have found a flat age curve for low-risk HPV $[25,35,36]$. Some authors have attributed the excess of low-risk HPV in older women to the elimination of highrisk HPV by the screening programs [35]. It is intriguing that while low-risk HPV incidence at younger ages is half as frequent and in some reports is undetectable twice as fast as high-risk HPV [37-39], it increases in frequency at older ages both in screened and unscreened women [40]. A recent study by Wheeler found the same 2 year clearance rate for low-risk (36\%), high-risk except 16 (41\%) and HPV 16 (34\%) (calculated from Table 3 in Wheeler 2006). The possibility that low-risk HPV in adult popula- tions results from frequent reactivation or re-infection should be considered in view of these data.

When comparing the HPV types found in these vaginal samples with the published data on HPV types isolated from cervical samples in Chile's general population [3] we found a remarkable coincidence in the distribution of high-risk HPV types (Fig 5) in vaginal and cervical swab samples. However, we found no similar correlation in the most frequent low-risk types (Figure 6). HPV DNA positivity was assessed in the cervical sample using a general primer-mediated $\mathrm{GP} 5+/ 6+$ polymerase chain reaction (PCR) and an Enzyme Immune Assay (EIA), to detect 36 HPV types (Ferreccio 2004), while in the current study, as already described, DNA was extracted and typed using PGMY consensus PCR and line blot assay to 37 HPV genotypes. However, these methods have been shown to have similar test characteristics, with difference in the detection of only 3 types: 35, 53 and 61 [41]. These results suggest that while self-collected vaginal swabs may result in higher low-risk HPV prevalence estimates compared to cervical swab samples, the concordance for high-risk, clinically relevant HPV is high $[9,12,42]$.

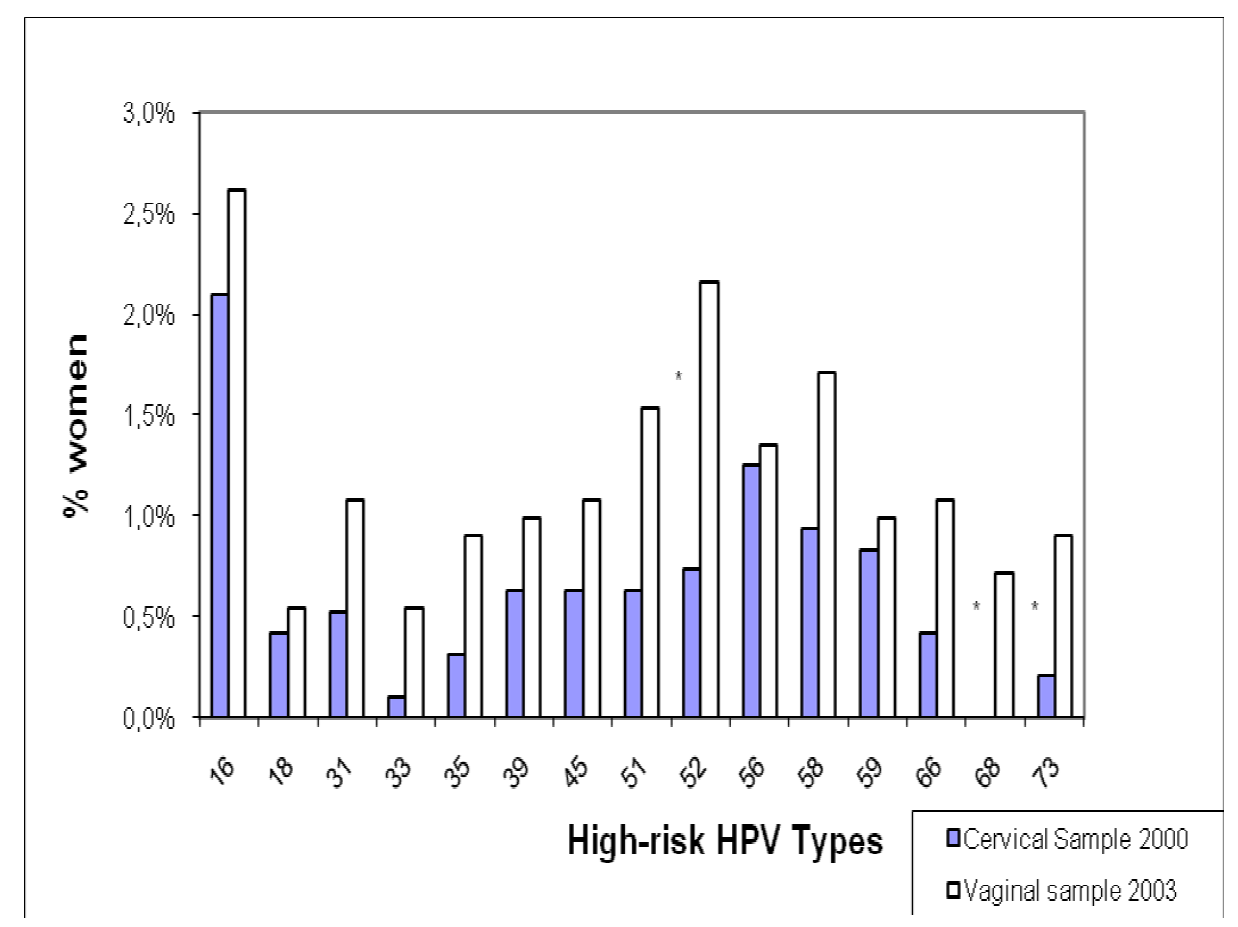

\section{Figure 5}

Types of High-risk HPV isolated from cervical samples in 2000 in Santiago and from vaginal self-collected samples in 2003 all Chile. Note: the asterisks denote a significant Chi square test with a $p$ value $<0.05$ for the difference in the proportion between cervical and vaginal samples. 


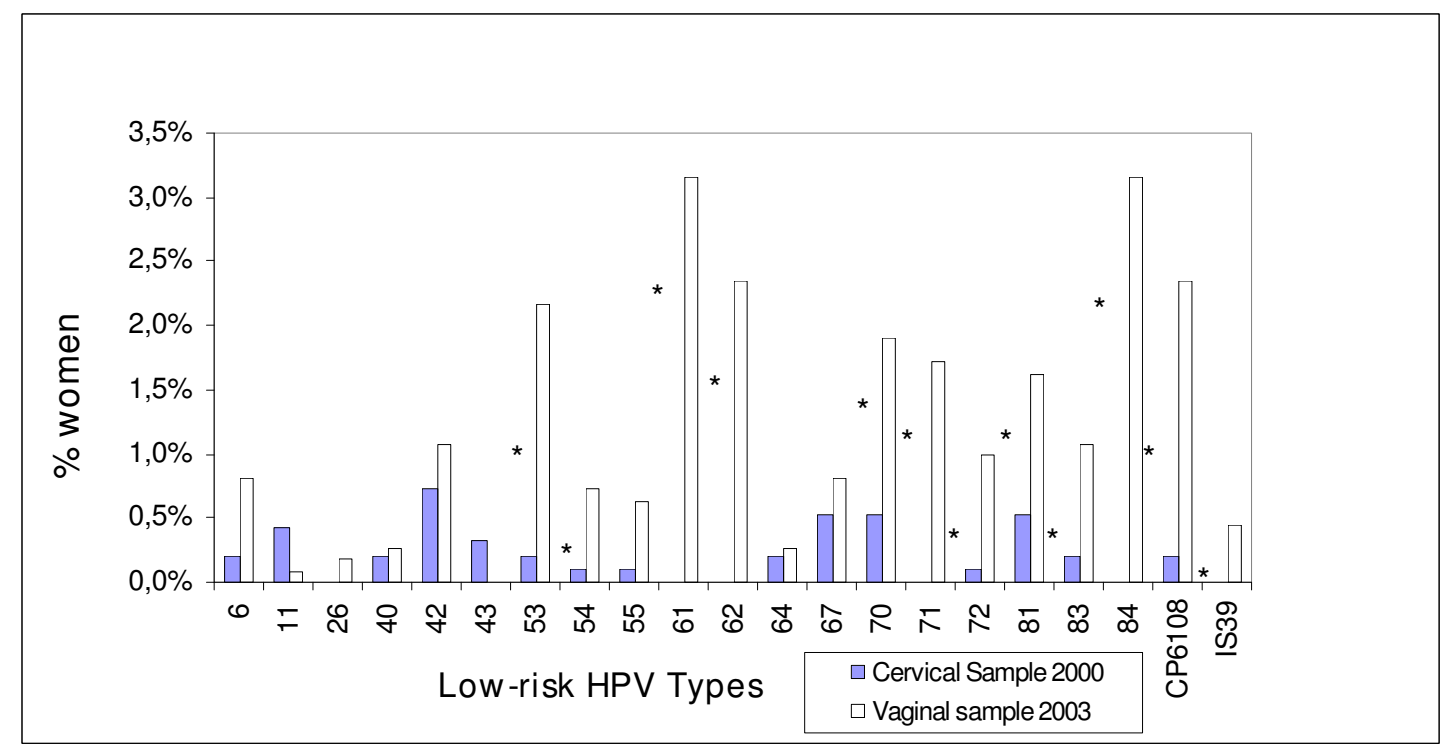

Figure 6

Types of low-risk HPV isolated from cervical samples in 2000 in Santiago and from vaginal self-collected samples in 2003 all Chile. Note: the asterisks denote a significant Chi square test with a $p$ value $<0.05$ for the difference in the proportion between cervical and vaginal samples.

Self-sampling was highly acceptable for Chilean women, as has been repeatedly demonstrated in different cultural settings in Canada [18], USA [16], Germany [13], Mexico [5], Brazil [19], Africa [8] and China [43]. Collectively, these data suggest that vaginal self-collected swabs could be effectively used for primary cervical cancer screening via HPV DNA testing. This application was particularly useful for those women who had never been screened, $70 \%$ of whom agreed to self-sample in our survey.

There are several caveats in the interpretations and generalizations based on this population-based survey of HPV type-specific prevalence. The relatively low response rate may bias the results. Nevertheless, since the non-participants are weighted, part of the bias may have been removed. We estimated the bias by correcting the estimates based on propensity scores, but the estimated prevalence changed minimally (Vives A. manuscript in preparation), therefore we believe that these biases do not significantly change our inferences.

The most important limitation in estimating the real HPV burden is the fact that we are measuring HPV at a single point in time, with no information about the historical exposure of these women to HPV. Winer and colleagues [44] estimated a cumulative HPV incidence of 32\% after 2 years of follow-up among young college women. HPV seroprevalence (cumulative lifetime exposure estimate) have been generated from a population survey $[45,46]$, with an average $15 \%-25 \%$ cumulative exposure to HPV 16 alone. Compared to the 3.2\% HPV 16 DNA observed in this population, clearly cervicovaginal HPV DNA point prevalence is not a valid marker of ever having been exposed to the virus.

\section{Conclusion}

Self-obtained vaginal sampling is an adequate method for monitoring the burden of HPV in the community. Coupling this sample collection with routine census procedures allows high-risk areas to be identified in order to prioritize interventions and to carry out routine surveillance to assess the impact of the interventions (e.g., HPV prophylactic vaccination) over time.

\section{Competing interests}

The author(s) declare that they have no competing interests.

\section{Authors' contributions}

CF conceived the study, and participated in its design and coordination and drafted the manuscript, AC carried out the extraction of DNA and coordinated the lab work, PM participated in the design of the study and coordination of field work, PV performed the statistical analysis. CG participated in study design and coordination, XA participated in study design and coordination, PG carried out the molecular studies and helped to draft the manuscript. All authors read and approved the final manuscript. 


\section{Acknowledgements}

Bárbara Miño for her work in sample preparation and DNA extraction, Alessandra Gederlini for collaboration in the statistical analysis, and LeeMin Duh for HPV genotyping. The Ministry of Health of Chile funded the ENS 2003 survey. The HPV study received additional support from Attila Lorincz from Digene for the sampling devices and from Roche Molecular Systems, Inc. for HPV PCR genotyping assays.

\section{References}

I. Schiller JT, Lowy DR: Prospects for cervical cancer prevention by human papillomavirus vaccination. Cancer Res 2006 , 66(2I): 10229-32.

2. Ames A, Gravitt P: Human papillomavirus vaccine update. Curr Infect Dis Rep 2007, 9(2): I5 |-8.

3. Ferreccio C, Prado RB, Luzoro AV, Ampuero SL, Snijders PJ, Meijer C), Vaccarella SV, Jara AT, Puschel KI, Robles SC, Herrero R, Franceschi SF, Ojeda JM: Population-based prevalence and age distribution of human papillomavirus among women in Santiago, Chile. Cancer Epidemiol Biomarkers Prev 2004, I 3( I 2):227|-6.

4. Clifford GM, Gallus S, Herrero R, Munoz N, Snijders PJ, Vaccarella S, Anh PT, Ferreccio C, Hieu NT, Matos E, Molano M, Rajkumar R, Ronco G, de Sanjose S, Shin HR, Sukvirach S, Thomas JO, Tunsakul S, Meijer CJ, Franceschi S, IARC HPV Prevalence Surveys Study Group: Worldwide distribution of human papillomavirus types in cytologically normal women in the International Agency for Research on Cancer HPV prevalence surveys: a pooled analysis. Lancet 2005, 366(9490):991-8.

5. Dzuba IG, Diaz EY, Allen B, Leonard YF, Lazcano Ponce EC, Shah KV, Bishai D, Lorincz A, Ferris D, Turnbull B, Hernandez Avila M, Salmeron J: The acceptability of self-collected samples for HPV testing vs. the pap test as alternatives in cervical cancer screening. J Womens Health Gend Based Med 2002, I I (3):265-75.

6. Gravitt PE, Lacey JV Jr, Brinton LA, Barnes WA, Kornegay JR, Greenberg MD, Greene SM, Hadjimichael OC, McGowan L, Mortel R, Schwartz PE, Zaino R, Hildesheim A: Evaluation of self-collected cervicovaginal cell samples for human papillomavirus testing by polymerase chain reaction. Cancer Epidemiol Biomarkers Prev 2001, I0(2):95-100.

7. Baldwin S, Santos C, Mendez Brown E, Nuno T, Giuliano A, Davis J, Garcia F: Comparison of type-specific human papillomavirus data from self and clinician directed sampling. Gynecol Oncol 2005, 97(2):6I2-7.

8. Safaeian M, Kiddugavu M, Gravitt PE, Ssekasanvu J, Murokora D, Sklar M, Serwadda D, Wawer MJ, Shah KV, Gray R: Comparability of Self-Collected Vaginal Swabs and Physician-Collected Cervical Swabs for Detection of Human Papillomavirus Infections in Rakai, Uganda. Sex Transm Dis 2007, 34(7):429-36.

9. Winer RL, Feng Q, Hughes JP, Yu M, Kiviat NB, O'reilly S, Koutsky LA: Concordance of Self-Collected and Clinician-Collected Swab Samples for Detecting Human Papillomavirus DNA in Women 18 to 32 Years of Age. Sex Transm Dis 2007, 34(6):37I-7.

10. Seo SS, Song YS, Kim JW, Park NH, Kang SB, Lee HP: Good correlation of HPV DNA test between self-collected vaginal and clinician-collected cervical samples by the oligonucleotide microarray. Gynecol Oncol 2006, I 02(I):67-73.

II. Kahn JA, Slap GB, Huang B, Rosenthal SL, Wanchick AM, Kollar LM, Hillard PA, Witte D, Groen P, Bernstein DI: Comparison of adolescent and young adult self-collected and clinician-collected samples for human papillomavirus. Obstet Gynecol 2004, I 03(5 Pt I):952-9.

12. Petignat P, Hankins C, Walmsley S, Money D, Provencher D, Pourreaux K, Kornegay J, Rouah F, Coutlee F, Canadian Women's HIV Study Group: Self-sampling is associated with increased detection of human papillomavirus. DNA in the genital tract of HIV-seropositive women. Clin Infect Dis 2005, 4 I (4):527-34.

13. Hillemanns P, Kimmig R, Huttemann U, Dannecker C, Thaler CJ: Screening for cervical neoplasia by self-assessment for human papillomavirus. DNA Lancet 1999, 354(9194): 1970.

14. Sellors JW, Lorincz AT, Mahony JB, Mielzynska I, Lytwyn A, Roth P, Howard M, Chong S, Daya D, Chapman W, Chernesky M: Comparison of self-collected vaginal, vulvar and urine samples with physician-collected cervical samples for human papillomavi- rus testing to detect high-grade squamous intraepithelial lesions. CMAJ 2000, I63(5):513-8.

15. Harper DM, Noll WW, Belloni DR, Cole BF: Randomized clinical trial of PCR-determined human papillomavirus detection methods: self-sampling versus clinician-directed--biologic concordance and women's preferences. Am J Obstet Gynecol 2002, I 86(3):365-73.

16. Serlin M, Shafer MA, Tebb K, Gyamfi AA, Moncada J, Schachter J, Wibbelsman $C$ : What sexually transmitted disease screening method does the adolescent prefer? Adolescents' attitudes toward first-void urine, self-collected vaginal swab, and pelvic examination. Arch Pediatr Adolesc Med 2002, I 56(6):588-9|.

17. Nobbenhuis MA, Helmerhorst TJ, van den Brule AJ, Rozendaal L, Jaspars LH, Voorhorst FJ, Verheijen RH, Meijer CJ: Primary screening for high risk HPV by home obtained cervicovaginal lavage is an alternative screening tool for unscreened women. J Clin Pathol 2002, 55(6):435-9.

18. Chernesky MA, Hook EW 3rd, Martin DH, Lane J, Johnson R, Jordan JA, Fuller D, Willis DE, Fine PM, Janda WM, Schachter J: Women find it easy and prefer to collect their own vaginal swabs to diagnose Chlamydia trachomatis or Neisseria gonorrhoeae infections. Sex Transm Dis 2005, 32(I 2):729-33.

19. Lippman SA, Jones HE, Luppi CG, Pinho AA, Veras MA, van de Wijgert JH: Home-Based Self-Sampling and Self-Testing for Sexually Transmitted Infections: Acceptable and Feasible Alternatives to Provider-Based Screening in Low-Income Women in Sao Paulo, Brazil. Sex Transm Dis 2007, 34(7):42 I-8.

20. República de Chile. Ministerio de salud. Encuesta Nacional de Salud [http://epi.minsal.cl/epi/html/invest/ENS/ENS.htm] Accessed July 162006

21. Kish L: A Procedure for Objective Respondent Selection within the Household. Journal of the American Statistical Association 1949, 44(247):380-387.

22. Taha NS, Focchi J, Ribalta JC, Castelo A, Lorincz A, Dores GB: Universal Collection Medium (UCM) is as suitable as the Standard Transport Medium (STM) for Hybrid Capture II (HC-2) assay. J Clin Virol 2006, 36(I):32-5.

23. Gravitt PE, Peyton CL, Apple RJ, Wheeler CM: Genotyping of 27 human papillomavirus types by using LI consensus PCR products by a single-hybridization, reverse line blot detection method. J Clin Microbiol I998, 36( I 0):3020-7.

24. Gravitt PE, Peyton CL, Alessi TQ, Wheeler CM, Coutlee F, Hildesheim A, Schiffman MH, Scott DR, Apple RJ: Improved amplification of genital human papillomaviruses. J Clin Microbiol 2000 , 38(I):357-6I.

25. Peyton CL, Gravitt PE, Hunt WC, Hundley RS, Zhao M, Apple RJ, Wheeler CM: Determinants of genital human papillomavirus detection in a US population. J Infect Dis 200I, I 83 (I I ): I 554-64.

26. Wolter KM: Introduction to Variance Estimation. New York: Springer-Verlag; 1985.

27. Dunne EF, Unger ER, Sternberg M, McQuillan G, Swan DC, Patel SS, Markowitz LE: Prevalence of HPV infection among females in the United States. JAMA 2007, 297(8):8I3-9.

28. Chan PKS, Chang AR, Cheung JLK, Chan DP, Xu LY, Tang NL, Cheng AF: Determinants of Cervical Human Papillomavirus Infection: Differences between High- and Low-Oncogenic Risk Types. J Infect Dis 2002, 1 85:28-35.

29. Luostarinen T, af Geijersstam V, Bjorge T, Eklund C, Hakama M, Hakulinen T, Jellum E, Koskela P, Paavonen J, Pukkala E, Schiller JT, Thoresen S, Youngman LD, Dillner J, Lehtinen M: No excess risk of cervical carcinoma among women seropositive for both HPVI 6 and HPV6/II. Int J Cancer 1999, 80(6):8I8-22.

30. Wheeler CM, Hunt WC, Schiffman M, Castle PE, Atypical Squamous Cells of Undetermined Significance/Low-Grade Squamous Intraepithelial Lesions Triage Study Group: Human papillomavirus genotypes and the cumulative 2-year risk of cervical precancer. Infect Dis 2006, I 94(9): I29|-9.

31. Bosch FX, Munoz N, de Sanjose S, Navarro C, Moreo P, Ascunce N, Gonzalez LC, Tafur L, Gili M, Larranaga I, Viladiu P, Daniel RW, Alonso de Ruiz P, Aristizabal N, Santamaria M, Guerrero E, Shah KV: Human papillomavirus and cervical intraepithelial neoplasia grade III/carcinoma in situ: a case-control study in Spain and Colombia. Cancer Epidemiol Biomarkers Prev 1993, 2(5):4I5-22.

32. Herrero R, Hildesheim A, Bratti C, Sherman ME, Hutchinson M, Morales J, Balmaceda I, Greenberg MD, Alfaro M, Burk RD, Wacholder S, Plummer M, Schiffman : Population-based study of 
human papillomavirus infection and cervical neoplasia in rural Costa Rica. J Natl Cancer Inst 2000, 92(6):464-74.

33. Castle PE, Schiffman M, Herrero R, Hildesheim A, Rodriguez AC, Bratti MC, Sherman ME, Wacholder S, Tarone R, Burk RD: A prospective study of age trends in cervical human papillomavirus acquisition and persistence in Guanacaste, Costa Rica. J Infect Dis 2005, I9I(I I):1808-16.

34. de Sanjose S, Diaz M, Castellsague X, Clifford G, Bruni L, Munoz N, Bosch FX: Worldwide prevalence and genotype distribution of cervical human papillomavirus DNA in women with normal cytology: a meta-analysis. Lancet Infect Dis 2007, 7(7):453-9.

35. Jacobs MV, Walboomers JM, Snijders PJ, Voorhorst FJ, Verheijen RH Fransen-Daalmeijer N, Meijer C): Distribution of 37 mucosotropic HPV types in women with cytologically normal cervical smears: the age-related patterns for high-risk and lowrisk types. Int J Cancer 2000, 87(2):22I-7.

36. Matos E, Loria D, Amestoy GM, Herrera L, Prince MA, Moreno J, Krunfly C, van den Brule AJ, Meijer Cl, Munoz N, Herrero R, Proyecto Concordia Collaborative Group: Prevalence of human papillomavirus infection among women in Concordia, Argentina: a population-based study. Sex Transm Dis 2003, 30(8):593-9.

37. Londesborough P, Ho L, Terry G, Cuzick J, Wheeler C, Singer A: Human papillomavirus genotype as a predictor of persistence and development of high-grade lesions in women with minor cervical abnormalities. Int J Cancer 1996, 69(5):364-8.

38. Giuliano AR, Papenfuss MR, Denman CA, de Zapien JG, Abrahamsen $M$. Hunter JB: Human papillomavirus prevalence at the USAMexico border among women $\mathbf{4 0}$ years of age and older. Int J STD AIDS 2005, 16(3):247-5I.

39. Brown DR, Shew ML, Qadadri B, Neptune N, Vargas M, Tu W, Juliar $B E$, Breen TE, Fortenberry JD: A longitudinal study of genital human papillomavirus infection in a cohort of closely followed adolescent women. J Infect Dis 2005, 191 (2): 182-92.

40. Franceschi S, Herrero R, Clifford GM, Snijders PJ, Arslan A, Anh PT, Bosch FX, Ferreccio C, Hieu NT, Lazcano-Ponce E, Matos E, Molano M, Qiao YL, Rajkumar R, Ronco G, de Sanjose S, Shin HR, Sukvirach $\mathrm{S}$, Thomas JO, Meijer J, Munoz N: Variations in the age-specific curves of human papillomavirus prevalence in women worldwide. Int / Cancer 2006, I I 9( I I ):2677-84.

41. Qu W, Jiang G, Cruz Y, Chang CJ, Ho GY, Klein RS, Burk RD: PCR detection of human papillomavirus: comparison between MY09/MYII and GP5+/GP6+ primer systems. J Clin Microbiol 1997, 35(6): |304-|3|0.

42. Petignat P, Faltin DL, Bruchim I, Tramer MR, Franco EL, Coutlee F: Are self-collected samples comparable to physician-collected cervical specimens for human papillomavirus DNA testing? A systematic review and meta-analysis. Gynecol Oncol 2007, I05(2):530-5.

43. Tisci S, Shen YH, Fife D, Huang J, Goycoolea J, Ma CP, Belinson J, Huang RD, Qiao YL: Patient Acceptance of Self-Sampling for Human Papillomavirus in Rural China. J Low Genit Tract Dis 2003, 7(2): 107-116.

44. Winer RL, Lee SK, Hughes JP, Adam DE, Kiviat NB, Koutsky LA: Genital human papillomavirus infection: incidence and risk factors in a cohort of female university students. Am J Epidemiol 2003, 157(3):218-26. Erratum in: Am J Epidemiol 2003; $157(9): 858$.

45. Stone KM, Karem KL, Sternberg MR, McQuillan GM, Poon AD, Unger $E R$, Reeves WC: Seroprevalence of human papillomavirus type 16 infection in the United States. J Infect Dis 2002, | 86(1 0): | 396-402.

46. Laukkanen P, Koskela P, Pukkala E, Dillner J, Laara E, Knekt P, Lehtinen $M$ : Time trends in incidence and prevalence of human papillomavirus type 6, II and 16 infections in Finland. J Gen Virol 2003, 84(Pt 8):2 105-9.

\section{Pre-publication history}

The pre-publication history for this paper can be accessed here:

http://www.biomedcentral.com/1471-2458/8/78/prepub
Publish with Biomed Central and every scientist can read your work free of charge

"BioMed Central will be the most significant development for disseminating the results of biomedical research in our lifetime. "

Sir Paul Nurse, Cancer Research UK

Your research papers will be:

- available free of charge to the entire biomedical community

- peer reviewed and published immediately upon acceptance

- cited in PubMed and archived on PubMed Central

- yours - you keep the copyright

Submit your manuscript here:

http://www.biomedcentral.com/info/publishing_adv.asp
BioMedcentral 